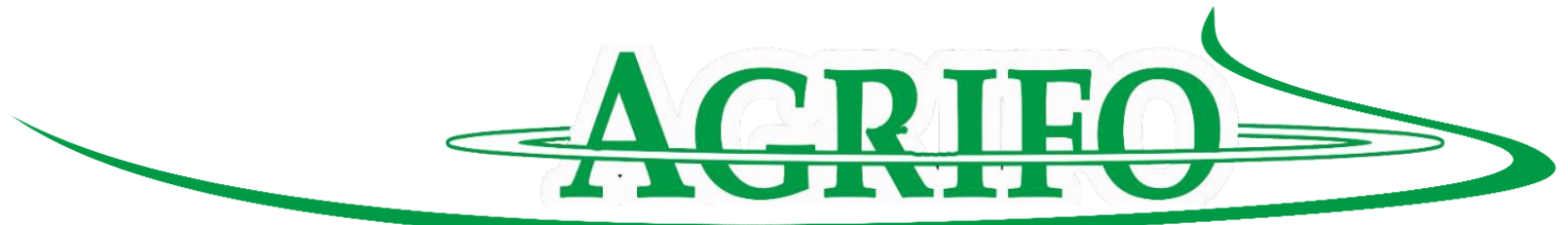

\title{
TINGKAT Hen Day Production (HDP) DAN Break Event Point (BEP) USAHA AYAM RAS PETELUR (Gallus sp)
}

\author{
Dewi Hastuti ${ }^{1}$, Rossi Prabowo ${ }^{1}$, Ahmad Anwar Syihabudin ${ }^{1}$
}

Corresponding Author: dewiunwahas@gmail.com

\section{ABSTRACT}

This study aims to determine the daily egg production level (HDP) and Break Event Point (BEP). The research location and respondents were determined intentionally (purposive sampling) with a total of 4 farmers consisting of 1,000 tail respondents, 1,350 heads, 4,500 heads and 6,000 heads. The data used are primary and secondary data. Data collection techniques are carried out by interviewing, recording and observing. The analysis model used is a descriptive analysis model with verbal and mathematical methods. The verbal method is a way of using words to explain a thing, while a mathematical method uses break event point (BEP) analysis. Based on the results of the study it was found that the production level of 51-day Hen Day production (HDP) of laying hens aged 85 weeks between $85.1 \%-85.3 \%$. Break Event Point (BEP) production obtained from a scale of 1,000 head was $30,379.5 \mathrm{~kg}, 1,350$ tails of $36,282.5 \mathrm{~kg}, 4,500$ tails of $124,180 \mathrm{~kg}$, and 6,000 tails of $159,231.5 \mathrm{~kg}$. Break Event Point (BEP) prices on a 1,000-tail scale of Rp. 16,893, 1,350 scale of Rp. 14,965, a 4,500 scale of Rp. 15,349 and the scale of 6,000 is Rp. 14,698. The conclusion of this study is that the HDP level is still below standard because the maintenance system for laying hens has not been maximized while the yield of the product and the rupiah is above the BEP value so that the laying hens business produces profits.

Keywords: Production, Laying Hens, BEP, Gunungpati

\section{PENDAHULUAN}

Tingkat pertumbuhan penduduk yang cukup tinggi menyebabkan kebutuhan akan pangan semakin meningkat, sehingga masalah pangan selalu lebih mendesak dan lebih utama disamping kebutuhan lain. Masalah pangan dalam hal pemenuhan gizi sampai saat ini masih menjadi salah satu masalah yang belum sepenuhnya dapat terpecahkan apalagi di daerah pedesaan dengan tingkat ekonomi yang masih rendah. Untuk mengatasi masalah tersebut, maka usaha peternakan ayam ras petelur merupakan salah satu alternatif pemecahan masalah pemenuhan gizi, terutama kekurangan protein hewani. Berdasarkan standar nasional tingkat konsumsi protein per hari per kapita 55 gram terdiri atas $20 \%$ protein hewani dan $80 \%$ protein nabati. Protein telur dapat untuk memenuhi kebutuhan gizi protein hewani (Sudarmono, 2003).

Ayam ras petelur adalah ayam betina dewasa yang dipelihara khusus untuk diambil telurnya. Asal mula ayam petelur adalah dari ayam hutan dan itik liar yang bertelur cukup banyak. Seleksi dilakukan oleh para pakar secara ketat, dengan tujuan pada hasil produksi telur yang banyak, ayam hutan tadi dapat diambil telur dan dagingnya maka arah seleksi spesifik pada hasil produksi telur yang banyak (Aziz, 2007).

Populasi ayam ras petelur di Kota Semarang mencapai 255.737 ekor dengan sentra produksi terdapat di

\footnotetext{
${ }^{1}$ Program Studi Agribisnis, Fakultas Pertanian, Univesitas Wahid Hasyim Semarang
} 
beberapa kecamatan seperti, Mijen, Ngaliyan dan Gunungpati. Di Kecamatan Gunungpati terdapat 13.582 ekor dengan jumlah 14 peternak (BPS, 2013). Meskipun jumlah populasi masih terbilang sedikit dibandingkan dengan kecamatan lain, meskipun demikian perkembangan usaha ayam ras petelur di Kecamatan Gunungpati terus berkembang dan mampu memenuhi kebutuhan masyarakat di sekitar daerah tersebut. Apalagi didukung dengan lokasi dan topografi yang sangat potensial yaitu berada pada ketinggian $259 \mathrm{~m}$ dpl dengan kisaran suhu sekitar $20^{\circ}-30^{\circ} \mathrm{C}$ dan dengan curah hujan rata - rata $1.845 \mathrm{~mm} /$ tahun sehingga keadaan tersebut mendukung terhadap produktifitas ayam ras petelur secara optimal. Hal ini sesuai dengan pendapat Santosa dan Sudaryani (2001) yang menyatakan suhu optimum kandang ayam ras petelur antara $21^{0}-27^{0} \mathrm{C}$.

Pengembangan usaha ayam ras petelur selain merupakan upaya untuk pemenuhan kebutuhan pangan hewani, juga memiliki prospek usaha kedepan yang cukup menjanjikan dan mampu untuk memperluas lapangan pekerjaan sehingga mampu meningkatkan pendapatan bagi masyarakat sekitar. Namun minimnya pengetahuan dan wawasan tentang tatalaksana dan menejemen usaha ayam ras petelur membuat para peternak enggan mengembangkan usaha tersebut.

Berdasarkan uraian latar belakang diatas maka dilakukan penelitian tentang tingkat produksi dan titik impas usaha ayam ras petelur. Adapun penelitian ini bertujuan untuk mengetahui tingkat produksi telur harian HDP dan BEP usaha ayam ras petelur di Kecamatan Gunungpati Kota Semarang.

\section{METODE PENELITIAN}

Penelitian ini dilalukan pada usaha ayam ras petelur yang berada di wilayah Kecamatan Gunungpati Kota Semarang. Penentuan lokasi ini dilakukan secara sengaja (purposive sampling), atas dasar pertimbangan bahwa daerah tersebut memiliki prospek yang bagus untuk usaha ayam ras petelur. Sedangkan penentuan responden secara insidental sampling dengan menemui dan mewawancarai secara langsung pemilik atau karyawan yang berkecimpung langsung dalam proses produksi. Sehingga didapatkan 4 responden dengan skala usaha ayam ras petelur 1.000 ekor, 1.350 ekor, 4.500 ekor dan 6.000 ekor, yang mampu memberikan data dan informasi yang relevan.

Data yang digunakan dalam penelitian ini adalah data primer dan data sekunder. Data primer diperoleh dengan melakukan observasi dan wawancara secara langsung kepada responden dengan memberikan kuesioner yang sesuai dengan tujuan penelitian, sedangkan data sekunder diperoleh melalui penelusuran literatur yang berhubungan dengan penelitian.

Model analisis yang digunakan yaitu model analisis deskriptif, yaitu menggunakan tabel tabel angka angka yang tersedia misalkan dari data produksi telur, biaya biaya, penerimaan, pendapatan kemudian melakukan uraian uraian serta analisis menggunakan rumus rumus ekonomi sesuai dengan tujuan penelitian. Rumus rumus yang digunakan:

$\mathrm{HDP}=\frac{\text { Jumlah produksi telur harian (Butir) }}{\text { Jumlah Ayam Petelur }} \times 100 \%$

Break event point (BEP) adalah teknis analisis untuk mempelajari antara biaya tetap, biaya variabel keuntungan dan volume kegiatan / titik impas usaha 
(Munawir, 2002). BEP dapat dirumuskan sebagai berikut:

$$
\begin{aligned}
& \text { BEP (produksi) }=\frac{\text { Total Biaya Produksi }}{\text { Harga Jual }} \\
& \text { BEP (harga) }=\frac{\text { Total Biaya Produksi }}{\text { Total Produksi }}
\end{aligned}
$$

\section{HASIL DAN PEMBAHASAN}

Peternakan ayam ras petelur di Kecamatan Gunungpati menggunakan kandang system battery. Kandang battery yaitu kandang yang berbentuk sangkar empat persegi panjang yang disusun secara berderet memanjang dan bertingkat tiga atau empat. Kandang battery juga dikenal sebagai kandang individual karena setiap sangkar hanya untuk satu ekor ayam. Kandang sistem ini dipandang lebih menguntungkan karena meningkatkan produktifitas ayam (Samadi, 2010). Ditambahkan oleh Nurcholis et al., (2009) yang menjelaskan bahwa keuntungan kandang sistem battery antara lain mempermudah pengontrolan ayam baik dari segi tingkat produktifitas individual, kesehatan dan pakan. Selain itu tingkat kanibalisme ayam dapat dihindari serta penyakit tidak mudah menjalar dari satu ayam ke ayam yang lainnya.

Strain pullet yang dipilih yaitu Isa Brown yang dibeli dari PT. Ciomas Karanganyar dengan umur 18 minggu. Pemilihan strain ini didasarkan atas beberapa pertimbangan diantaranya, produktivitas dan bobot telur tinggi, konversi ransum rendah, daya hidup tinggi, dan masa bertelur panjang. Menurut Rasyaf (2006) indikator bibit ayam yang baik yaitu tidak cacat pada badan, mata jernih, bulu halus serta mengkilap, Nampak aktif, lincah, gesit, nafsu makan baik, seragam dan mata waspada.

Pemberian pakan ayam ras petelur diberikan 2 kali sehari yaitu pagi dan sore hari. Frekuensi pemberian pakan sama yang dilakukan peternak di populer farm yaitu pemberian pakan dilakukan secara manual (tenaga manusia) 2 kali sehari pagi jam 08.00 WIB sebanyak $50 \%$ dan siang hari pukul 13.00 WIB sebanyak $50 \%$, pemberian pakan bertujuan untuk menghindari pakan tumpah dan tercecer. Untuk menghindari pakan tumpah atau tercecer ,pemberian pakan harus diatur sesuai dengan jumlah yang dibutuhkan (Nurcholis et al., 2009). Marginingtyas et al., (2015), menyatakan bahwa pemberian nutrisi kepada ayam ras petelur tidak sama satu dengan yang lain karena kadar nutrisi yang diberikan dipengaruhi oleh umur ayam. Bahan pakan yang digunakan yaitu campuran antara dedak, konsentrat dan jagung.

Penyakit yang terjadi pada ternak ayam, umumnya timbul bila keadaan pemeliharaan kurang baik, kondisi kandang yang tidak memenuhi syarat kesehatan disertai pemberian ransum yang kurang sempurna. Akibat dari serangan penyakit ini menyebabkan kerugian yang sangat besar pada peternakan. Untuk menjaga agar ayam yang dipelihara tetap sehat, perlu dilakukan upaya-upaya Pencegahan penyakit. Upaya - upaya tersebut diantaranya :sanitasi, vaksinasi dan penggunaan obat-obatan yang dicampur makanan/air minum yang berbentuk feed supplement dan lain sebagainya.

Pengumpulan telur dilakukan sebanyak tiga kali. Telur pertama diambil pukul 10.00 WIB sampai pukul 11.00 WIB, pengambilan kedua dilakukan pada siang hari pukul 13.00 WIB sampai pukul 14.00 WIB dan 
pengambilan ketiga dilakukan pada pukul 15.00 WIB sampai 16.00 WIB kemudian telur dikumpulkan di egg tray. Setelah semua telur terkumpul proses sejanjutnya yaitu penyortiran telur sesuai dengan bentuk apakah utuh maupun tidak sebelum di timbang kemudian dimasukkan kedalam peti yang terbuat dari kayu sebelum dipasarkan.

\section{Hen Day production (HDP)}

Hen Day production (HDP) adalah cara menghitung telur harian. Tujuan perhitungan HDP adalah untuk mengetahui jumlah telur yang dihasilkan oleh sekelompok ayam pada umur tertentu. Adapun Hen Day Production (HDP) dapat dilihat pada tabel 1.

Tabel 1. Hen Day Production Pada Peternakan Ayam Ras Petelur

\begin{tabular}{|c|c|r|r|r|r|}
\hline $\begin{array}{c}\text { Umur } \\
\text { (Minggu }\end{array}$ & Skala (Ekor) & $\begin{array}{c}\text { Jumlah Telur } \\
\text { (Butir) }\end{array}$ & Hen Day \% & $\begin{array}{c}\text { Standar Hen } \\
\text { Day \% }\end{array}$ & $\begin{array}{c}\text { Kekurangan } \\
\%\end{array}$ \\
\hline 51 & 1.000 & 853 & 85,3 & 88,8 & $-3,5$ \\
\hline 51 & 1.350 & 1.150 & 85,2 & 88,8 & $-3,6$ \\
\hline 51 & 4.500 & 3.830 & 85,1 & 88,8 & $-3,7$ \\
\hline 51 & 6.000 & 5.112 & 85,2 & 88,8 & $-3,6$ \\
\hline
\end{tabular}

Berdasarkan tabel diatas dapat diketahui bahwa Hen Day Production (HDP) di peternakan ayam ras petelur di Kecamatan Gunungpati umur 51 minggu antara $85,1 \% \quad 85,3 \%$. Sementara Hen Day standart menurut (ISA A GENETICS COMPANY) sebesar $88,8 \%$. Dengan demikian menjelaskan bahwa sistem pemeliharaan ayam ras petelur belum maksimal karena masih berada di bawah nilai standart yang berkisar 3,5\% - 3,7\%. Kekurangan tersebut dipengaruhi oleh banyak faktor antara lain pakan dan vitamin. Pemberian pakan yang tidak sesuai dengan standar mengakibatkan berkurangnya asupan nutrisi sehingga akan berpengaruh terhadap turunnya tingkat produksi. Pemberian pakan kepada ayam ras petelur tidak sama antara satu dengan yang lainnya karena kadar pakan yang diberikan dipengaruhi oleh umur ayam. Pemberian pakan di peternakan ayam ras petelur rata-rata sebesar $110 \mathrm{gr}$ per hari per ekor sedangkan menurut standar dari (Isa A Genetics Company) yaitu sebesar 122 gr per hari per ekor. Hal ini jelas menggambarkan bahwa pemberian pakan tidak sesuai. Menurut Tumion et al., (2017), menyatakan bahwa produksi telur yang baik harus disesuaikan dengan kualitas dan kuantitas pakan karena produksi dan kualitas telur akan maksimal apabila kualitas pakan yang diberikan dapat memenuhi kebutuhan berdasarkan umur dan tatalaksana pemeliharaan. Faktor yang mempengaruhi pada produksi telur menurut Yuwanta (2008) adalah originalitas ayam, umur ayam, umur dewasa kelamin, berat ayam, moulting, faktor lingkungan seperti temperatur dan pencahayaan, pakan dan pembatasan pakan.

\section{Biaya produksi}

Biaya produksi adalah biaya yang dikeluarkan oleh peternakan ayam ras petelur mulai dari hulu sampai ke hilir sampai peternakan tersebut mendapatkan produk utama berupa telur ayam ras sampai telur tersebut dipasarkan sehingga peternakan tersebut mendapatkan suatu keuntunggan. Biaya produksi meliputi biaya tetap dan biaya variabel. Biaya tetap yang dikeluarkan antara lain biaya penyusutan kandang, 
biaya penyusutan peralatan dan pajak bumi dan bangunan (PBB). Sedangkan biaya variabel yang dikeluarkan antara lain biaya pullet, biaya pakan, biaya OVK, biaya listrik, biaya tenaga kerja dan biaya transportasi. Rata-rata total biaya yang dikeluarkan dalam usaha peternakan ayam petelur selama satu periode dapat dilihat pada tabel 2 sebagai berikut:

Tabel 2. Biaya produksi peternakan ayam ras petelur

\begin{tabular}{lccccc}
\hline \multirow{2}{*}{ Uraian } & & \multicolumn{4}{c}{ Skala (Ekor) } \\
\cline { 2 - 6 } & Tetap & 5.768 .750 & 9.364 .100 & 27.218 .750 & 32.743 .750 \\
\hline $\begin{array}{l}\text { Biaya } \\
\text { Rp/Periode) }\end{array}$ & Variabel & 541.062 .500 & 643.722 .500 & 2.208 .020 .000 & 2.833 .425 .000 \\
\hline $\begin{array}{l}\text { Biaya } \\
\text { (Rp/Periode) }\end{array}$ & Produksi & 546.831 .250 & 653.086 .600 & 2.235 .238 .750 & 2.866 .168 .750 \\
\hline $\begin{array}{l}\text { Biaya } \\
\text { (Rp/Periode) }\end{array}$ & & & &
\end{tabular}

Berdasarkan uraian biaya tersebut dapat kita lihat bahwa biaya pakan merupakan biaya terbesar dalam budidaya ayam ras petelur sejalan dengan pendapat Dewanti dan Sihombing (2012) karena tiap hari ternak membutuhkan pakan untuk bertahan hidup dan berproduksi. Besarnya biaya pakan berkisar antara 60\% - 80\% dari total biaya. Total Biaya produksi tertinggi yang dikeluarkan terdapat pada peternak skala 6.000 ekor sebesar Rp. 2.866.168.750,- sedangkan biaya produksi terendah pada skala 1.000 ekor sebesar Rp. 546.831.250,-. Dari hasil diatas dapat kita ketahui bahwa perbedaan besaran biaya produksi dipengaruhi oleh skala usaha peternakan. Semakin besar populasi ayam yang dipelihara, maka pendapatan yang diperoleh relatif besar pula, demikian juga dengan penerimaan dan biaya produksi yang dikeluarkan (Maliki et al., 2017, Maulana et al., 2017).

\section{Penerimaan}

Penerimaan usaha peternakan ayam merupakan seluruh penerimaan peternakan dari penjualan hasil produksi. Penerimaan diperhitungkan hanya dalam wujud tunai yang diterima oleh responden dari hasil penjualan saja yang diperhitungkan dalam penerimaan (Dewanti dan Sihombing, 2012). Penerimaan yang diperoleh selanjutnya digunakan untuk menutupi biaya total yang telah dikeluarkan. Oleh karena itu dalam usaha ayam ras petelur perlu dilakukan efesiensi biaya untuk meningkatkan pendapatan. Penerimaan pada penelitian ini terdiri dari penjualan telur dan penjualan ayam afkir.. Data lebih rinci dapat dilihat pada Tabel 3.

Tabel 3. Penerimaan Pada Peternakan Ayam Ras Petelur

\begin{tabular}{lrrrr}
\hline \multirow{1}{*}{ Uraian } & \multicolumn{4}{c}{ Skala (Ekor) } \\
\cline { 2 - 5 } & \multicolumn{1}{c}{1.000} & 1.350 & \multicolumn{1}{c}{4.500} & \multicolumn{1}{c}{6.000} \\
\hline Penjualan Telur (Rp) & 580.554 .000 & 782.749 .500 & 2.611 .888 .500 & 3.497 .325 .000 \\
\hline $\begin{array}{l}\text { Penjualan Ayam Afkir } \\
\text { (Rp) }\end{array}$ & 40.500 .000 & 54.675 .000 & 192.375 .000 & 256.500 .000 \\
\hline Penerimaan (Rp) & 621.054 .000 & 837.424 .500 & 2.804 .263 .500 & 3.753 .825 .000 \\
\hline
\end{tabular}


Tabel 3 menunjukkan bahwa, total penerimaan berbeda-beda, hal tersebut dapat dilihat dari sebaran jumlah skala usaha yang beragam. Jumlah skala usaha yang dijalankan sangat berpengaruh terhadap penerimaan peternak. Maulana et al., (2017) menyatakan semakin besar populasi ayam yang dipelihara semakin tinggi penerimaan produksi yang diperoleh. Populasi ayam yang semakin banyak akan mengakibatkan semakin tinggi penjualan ayam. Banyak nya populasi ayam yang dipelihara juga berpengaruh terhadap hasil kotoran dan karung bekas pakan. Dari hasil perhitungan didapat penerimaan tertinggi yaitu skala 6.000 ekor sebesar Rp. 3.753.825.000,- dan penerimaan terendah yaitu skala 1.000 ekor sebesar
Rp. 621.054.000,-. Hasil penjualan telur dan ayam afkir kemudian dijumlahkan untuk mengetahui total penerimaan. Total penerimaan harus lebih tinggi dari total biaya karena total penerimaan akan dikurangi dengan biaya total untuk memperoleh keuntungan. Semakin tinggi selisih antara total penerimaan dengan total biaya maka semakin tinggi pula keuntungan yang diperoleh peternak ayam ras petelur.

Pendapatan

Pendapatan adalah selisih antara penjualan hasil produksi dengan biaya usaha. Rata-rata pendapatan pada usaha peternakan ayam petelur dapat dilihat pada Tabel 4. sebagai berikut:

Tabel 4. Pendapatan Pada Peternakan Ayam Ras Petelur

\begin{tabular}{lccrr}
\hline \multirow{2}{*}{ Uraian } & \multicolumn{4}{c}{ Skala (Ekor) } \\
\cline { 2 - 5 } & 1.000 & 1.350 & 4.500 & \multicolumn{1}{c}{6.000} \\
\hline Penerimaan (Rp) & 621.054 .000 & 873.424 .500 & 2.804 .263 .500 & 3.753 .825 .000 \\
\hline Biaya Produksi (Rp) & 546.831 .250 & 653.086 .600 & 2.235 .238 .750 & 2.866 .168 .750 \\
\hline Pendapatan (Rp) & 74.222 .750 & 184.337 .900 & 569.024 .750 & 887.656 .250 \\
\hline
\end{tabular}

Tabel 4. menunjukkan bahwa, Pendapatan tertinggi terdapat pada skala 6.000 ekor sebesar Rp. 887.656.250,dan pendapatan terendah terdapat pada skala 1.000 ekor sebesar Rp. 74.222.750,-. Perbedaan pendapatan usaha peternakan ayam ras petelur dipengaruhi oleh besaran biaya produksi yang dikeluarkan dengan jumlah skala usaha yang dimiliki. Dengan arti lain bahwa besarnya biaya produksi yang dikeluarkan seimbang dengan jumlah populasi ternak yang dimiliki sehingga pendapatan akan semakin besar. Hal ini sesuai dengan pendapat Triana et al., (2007) bahwa biaya produksi yang besar dan seimbang dengan skala usaha maka tingkat pendapatan peternak akan semakin besar pula bila sistem pengelolaannya dilakukan secara optimal. Selanjutnya ditambahkan oleh Fitriza et al., (2012) bahwa jumlah ternak yang dipelihara akan mempengaruhi besarnya pendapatan yang diperoleh peternak, semakin banyak ayam yang dipelihara maka semakin tinggi pendapatan yang diperoleh peternak.

\section{Break Event Point (BEP)}

Break Event Point (BEP) menunjukkan titik impas dimana kondisi usaha tidak untung dan tidak rugi. Artinya dalam kondisi ini jumlah penerimaan yang diterima sama dengan jumlah biaya yang dikeluarkan. Analisis BEP memberikan pedoman tentang berapa jumlah produk minimal yang harus di produksi atau dijual dan pada harga jual berapa tidak untung dan tidak rugi. Manfaat lain analisis titik impas 
adalah membantu pengambilan permintaan (produksi) dan penentuan keputusan dalam hal aliran kas, jumlah harga suatu produk (Kasmir, 2008).

Tabel 5. BEP Pada Peternakan Ayam Ras Petelur

\begin{tabular}{lrrrr}
\hline \multirow{2}{*}{ Uraian } & \multicolumn{4}{c}{ Skala (Ekor) } \\
\cline { 2 - 5 } & \multicolumn{1}{c}{1.000} & \multicolumn{1}{c}{1.350} & \multicolumn{1}{c}{4.500} & \multicolumn{1}{c}{6.000} \\
\hline Biaya Produksi (Rp) & 546.831 .250 & 653.086 .600 & 2.235 .238 .750 & 2.866 .168 .750 \\
\hline Harga Jual (Rp) & 18.000 & 18.000 & 18.000 & 18.000 \\
\hline Total Produksi (Rp) & 32.370 & 43.641 & 145.626 & 195.000 \\
\hline BEP Produksi $(\mathrm{Kg})$ & $30.379,5$ & $36.282,5$ & 124.180 & $159.231,5$ \\
\hline BEP Harga $(\mathrm{Rp})$ & 16.893 & 14.965 & 15.349 & 14.698 \\
\hline
\end{tabular}

Tabel 5 menunjukan bahwa untuk mencapai kondisi BEP peternak harus menjual produknya (telur) sesuai dengan biaya produksi yang dikeluarkan. Semakin besar biaya produksi yang dikeluarkan semakin banyak pula produk yang harus dijual begitupun sebaliknya. Suparno dan Maharani (2017), menyampaikan masing-masing peternakan ayam ras petelur memiliki jumlah produk dan pendapatan yang berbeda untuk mencapai kondisi BEP nya. Perbedaan tersebut dipengaruhi olah besarnya jumlah biaya tetap usaha itu sendiri. Semakin besar jumlah biaya tetap maka penjualan produknya juga semakin banyak guna menutup biaya tetap yang dikeluarkan. Sebagai contoh peternakan dengan skala 6.000 ekor mengeluarkan biaya produksi sebesar Rp. 2.866.168.750 dengan produksi telur sebanyak $195.000 \mathrm{~kg}$ dengan harga jual Rp. 18.000. Sedangkan BEP produksi sebanyak $159.231,5 \mathrm{~kg}$ dan BEP harga sebesar Rp. 14.698. Dari keterangan tersebut dapat diartikan bahwa peternakan ayam ras petelur mampu menghasilkan keuntungan dikarenakan penghasilan produk maupun rupiah nya mampu diatas nilai BEP.

\section{KESIMPULAN}

Berdasarkan hasil dan pembahasan yang telah dilakukan maka dapat ditarik kesimpulan sebagai berikut:
1. Tingkat produksi Hen Day production (HDP) peternakan ayam ras petelur umur 51 minggu adalah 85,1\%-85,3\%. Sementara HDP standar sebesar $88,8 \%$. Hal ini menunjukkan bahwa sistem pemeliharaan ayam ras petelur di Kecamatan Gunungpati belum maksimal.

2. Break Event Point (BEP) produksi yang di peroleh dari usaha peternakan ayam ras petelur berturut-turut dari skala 1.000 ekor sampai 6.000 ekor yaitu $30.379,5 \mathrm{~kg}$, $36.282,5 \mathrm{~kg}, \quad 124.180 \mathrm{~kg}$, dan $159.231,5 \mathrm{~kg}$. Sedangkan output usaha peternakan ayam ras petelur tersebut sebesar $32.370 \mathrm{~kg}, 43.641$ $\mathrm{kg}, 145.626 \mathrm{~kg}$, dan $195.000 \mathrm{~kg}$. Break Event Point (BEP) harga skala 1.000 ekor sebesar Rp. 16.893, skala 1.350 ekor sebesar Rp. 14.965, selanjutnya skala 4.500 ekor sebesar Rp. 15.349 serta skala 6.000 ekor sebesar Rp. 14.698. Sedangkan harga jual telur dari ke empat peternak yaitu sebesar Rp. 18.000,-. Dengan demikian dapat di tarik kesimpulan bahwa usaha peternakan ayam ras petelur mendapat keuntungan karena output yang dihasilkan diatas BEP serta harga jual telur berada di atas BEP harganya. 


\section{DAFTAR PUSTAKA}

Aziz, D. (2007). Mengenal Ayam Petelur. Jakarta: CV. Sinar Cemerlang Abadi

Badan Pusat Statistik Kota Semarang. (2013).

Dewanti, R. dan Sihombing, G. (2012). Analisis Pendapatan Usaha Peternakan Ayam Buras (Studi Kasus Di Kecamatan Tegalombo, Kabupaten Pacitan). Jurusan Peternakan. Fakultas Pertanian. Universitas Sebelas Maret. Surakarta. Buletin Peternakan Vol. 36(1): 48-56.

Fitriza, Y. T., F. T. Haryadi, dan S. P. Syahlani. (2012). Analisis pendapatan dan persepsi peternak plasma terhadap kontrak perjanjian pola kemitraan ayam pedaging di Provinsi Lampung. Buletin Peternakan. 36 (1) : 57- 65.

Kasmir. (2008). Analisis Laporan Keuangan. Jakarta: Rajawali Pers.

Maliki, M. L. Setiadi, A., dan Sarengat, W. ( 2017 ). AnalisisPofitabilitas Usaha Peternakan Ayam Petelur Di Suyatno Farm Desa Kalisidi Kecamatan Ungaran Barat Kabupaten Semarang. Fakultas Peternakan dan Pertanian. Universitas Diponegoro Semarang. Jurnal Mediagro Vol. 13. (1): 49 - 60. Faperta, Unwahas.

Marginingtyas, E., W.F. Muhmudy dan Indriati. (2015). Penentuan Komposisi Pakan Ternak Untuk Memenuhi Kebutuhan Nutrisi Ayam Petelur dengan Biaya Minimum Menggunakan Algoritma Genetika. Jurnal
Mahasiswa PTIIK. Universitas Brawijaya. Vol 5 (12) : 1-7.

Maulana, F.H. Prasetyo, E. dan Sarenggat, W. (2017). Analisis Pendapatan Usaha Peternakan Ayam Petelur Sumur Banger Farm Kecamatan Tersono Kabupaten Batang. Fakultas Peternakan dan Pertanian. Universitas Diponegoro Semarang. Jurnal Mediagro Vol 13 (2): 1 - 412. Faperta, Unwahas.

Munawir, S. (2002). Analisis Laporan Keuangan. Liberty. Yogyakarta.

Nurcholis, Dewi, H., dan Barep, S. (2009), Tatalaksana Pemeliharaan Ayam Ras Petelur Periode Layer Di Populer Farm Desa Kuncen Kecamatan Mijen Kota Semarang. Jurnal Mediagro Vol 5 (2): 38 - 49. Faperta, Unwahas.

Rasyaf, M. (2006). Panduan Beternak Ayam Petelur. Jakarta : Penerbit Swadaya.

Samadi, B. (2010). Sukses Beternak Ayam Ras, Pedaging dan Petelur. Jakarta : Pustaka Mina.

Sudarmono, As. (2003). Pedoman pemeliharaan ayam ras petelur, Yogyakarta : Kanisius.

Suparno dan Maharani, D.(2017). Analisis Kelayakan Usaha Peternakan Ayam Ras Petelur di Kecamatan Abunten, Kabupaten Sumenep. Jurnal Maduranch Vol 2 (1) Fakultas Pertanian. Universitas Madura.

Triana, A., T. Salam, dan M. Muis. (2007). Analisis pendapatan usaha peternakan ayam ras petelur periode layer di Kecamatan Cenrana Kabupaten 
Maros. Jurnal Agrisistem Vol 3 (1): 11-25.

Tumion, B. V.V.J. Panalewen, A. Makalew, B. Rorimpandey. (2017). Pengaruh Biaya Pakan Dan Tenga Kerja Terhadap Keuntungan Usaha Ayam Ras Petelur Vony Kanaga Di Kelurahan Tawaan Kota Bitung. Jurnal Zootek Vol. 37 (2 ): 207215. Fakultas Peternakan .Univesitas Sam Ratulangi Manado.

Yuwanta, T.( 2008). Budidaya Ternak Unggas Petelur. Yogyakarta : Penerbit Kanisius. 